\author{
Asian Journal of \\ Medical and Biological Research \\ ISSN 2411-4472 (Print) 2412-5571 (Online) \\ www.ebupress.com/journal/ajmbr
}

\title{
Article \\ Preparation of wastelage with poultry droppings and rice straw (Oryza sativa L.) as a cattle feed
}

\author{
Obydul Islam $^{1 *}$, Somaya Akter ${ }^{1}$, Md. Ahidul Islam ${ }^{2}$, Dewan Kamruzzaman Jamee ${ }^{1}$ and Rokibul Islam Khan ${ }^{1}$ \\ ${ }^{1}$ Department of Animal Science, Bangladesh Agricultural University, Bangladesh \\ ${ }^{2}$ Department of Animal Science, Patuakhali Science and Technology University, Bangladesh
}

*Corresponding author: Obydul Islam, Department of Animal Science, Bangladesh Agricultural University, Mymensingh-2202, Bangladesh. E-mail: obydulraju@gmail.com

Received: 14 August 2018/Accepted: 20 September 2018/ Published: 30 September 2018

\begin{abstract}
The use of poultry droppings as a feed ingredient may not only reduce waste and environmental pollution but also provide inexpensive feed components for ruminants. An experiment was conducted to prepare wastelage in the field laboratory of Animal Science Department, Bangladesh Agricultural University, Mymensingh. Rice straw (Oryza sativa L.) was mixed with 0\%, 10\%, 20\% and 30\% caged layer excreta (CLE) and 5\% molasses in each treatment on dry matter (DM) basis and ensiled in air tight container under room temperature. After 60 days, ensiled mixture was opened. All the wastelage had desirable smell, light brownish color, soft texture and no fungal growth was found. Results revealed that $\mathrm{P}^{\mathrm{H}}, \mathrm{DM}$, crude protein $(\mathrm{CP})$, crude fiber $(\mathrm{CF})$, ash, in vitro organic matter digestibility and metabolizable energy were significantly $(\mathrm{p}<0.05)$ influenced by different levels of CLE. The highest CP (5.97g/100g DM) was observed in wastelage with $30 \%$ CLE $(\mathrm{p}<0.05)$ followed by $20 \%$ and $10 \%$ CLE. The $\mathrm{P}^{\mathrm{H}}$ level, DM, Ash and CF contents were decreased linearly ( $\mathrm{p}<0.05$ ) from 4.8 to $4.11,78.00$ to $55.63,25.08$ to 17.70 and 22.57 to $14.95 \%$, respectively as the level of CLE increased from 0 to $30 \%$. In all treatments, EE content was not significantly influenced by the different level of CLE. The in vitro organic matter digestibility (IVOMD) and metabolizable energy (ME) also increased significantly $(\mathrm{p}<0.05)$ with the increased level of CLE and maximum value $(57.51 \%$, and $8.12 \mathrm{MJ} / \mathrm{Kg} \mathrm{DM}$, respectively) was obtained in wastelage with 10\% CLE, which is statistically identical with 20\% CLE. Therefore, it could be speculated that ensiling rice straw with up to 20\% CLE improved the feeding value of wastelage.
\end{abstract}

Keywords: caged layer excreta; rice straw; ensiling; digestibility; wastelage

\section{Introduction}

Rice straw is the main feed for cattle and buffalo available in the Bangladesh. But rice straw is a poor quality feed because of higher lignocellulose complex and poor digestibility, high fiber, low protein content, lack of easily available energy and low content of essential minerals such as Phosphorus and Sulfur. A suitable technology for improving feed value of rice straw lies in the fact that how much it is acceptable to the farmers and finally the technology itself should have socio-economic importance (Jayasuriya and Pearce, 1983). It is realized that only possible alternative for better utilization of straw is to improve digestibility of this straw in the ruminants by feeding pre-treated straw. In recent years, agro-industrial wastes e.g. poultry droppings, cow dung, sugarcane biogases, wood pulp and slaughter house wastes have attracted the attention to the nutritionists for their economical and nutritional potentialities for the feeding of animals (El-Sabban et al., 1970).

Nutritional value of poultry droppings as feed for ruminants has considerable monetary value and much more valuable as source of feed than for fertilizer or methane generation. Performance of cattle fed diets containing animal wastes is similar to that of animals fed conventional diets (Harvey et al., 1996). Litter must be processed prior to its use as an animal feed for the elimination of pathogens and enhancement of palatability (Fontenot, 
1990). Martin et al. (1998) showed in their survey of 86 samples of poultry litter processed by different methods that no pathogenic bacteria are present in poultry litter regardless of its processing method. Poultry wastes are higher in nutritional value and can be a valuable feed for ruminant (Fontenot et al., 1971). It contains about 28$30 \%$ crude protein out of which $36-50 \%$ is true protein (Bhattacharya and Taylor, 1975). Poultry droppings are a good source of protein and can compete favorably with any other protein sources and do not contain any antinutritional substances in animal diet (Douglas, 1990). Poultry wastes are higher in nutritional value than other animal wastes and especially rich in crude protein and minerals.

The utilization of the waste as feed for ruminant became a convenient option of disposing of the wastes (Mavimbela, 2000). Ruminant have the ability to digest low quality feedstuffs that are not usable by other livestock species. One such feedstuff is poultry manure, which provides opportunities for both the poultry producer and the beef producer. The large quantities of manure produced during modern poultry production are expensive to dispose safely. Feeding poultry excreta is a means of disposing of a waste product while concurrently supplying a low-cost protein feed to ruminant. Poultry waste can be rendered free of pathogens by ensiling (Hadjipanayiotou, 1982; Daniels et al., 1983) and deep stacking (Strickler, 1977). These ensiled mixtures may be utilized as an important source of protein and energy in the diet of ruminants. Addition of molasses and ensiling of crop residues can be the effective means of improving the nutritive value. It is suitable for feeding ruminants as it is wholesome, effective, palatable, dust free and promotes fermentation. It helps in facilitating the natural preservation by lowering the $\mathrm{pH}$ and producing lactic acid bacteria. Wastelage with poultry droppings was found to be a satisfactory supplemental protein source for lactating dairy cattle (Sitorus $e t$ al., 1980), beef cattle (Cooper et al., 1974), and also sheep (Goering and Smith, 1977). Poultry droppings may be an important source of protein as well as energy for ruminants. A large number of researchers did not find any significant differences in the carcass or its quality. Fontenot et al. (1971) found that broiler litter to finishing beef steers did not adversely affect the taste of the meat. Many scientists have reported no significant effects of feeding poultry waste on milk composition, and flavor (NRC, 1983).

Ensiling of chopping rice straw along with poultry droppings and molasses may produce a good quality wastelage for feeding cattle having desire palatability, nutrient content and digestibility. So, ensiling rice straw with poultry excreta and molasses will increase crude protein and other nutritive value of the diet. Ensiling poultry excreta may be a simple and low cost option, of disposing poultry droppings and reducing feed cost for ruminant. Considering the above evidence the present study was under taken to find out a convenient option of proper recycling of poultry droppings, to evaluate the nutritive value of rice straw ensiled with caged layer excreta (CLE) and molasses in varying proportions as well as to determine the optimum proportion of caged layer excreta (CLE) and ensiling period that will improve the feed value of rice straw.

\section{Materials and Methods}

\subsection{Collection of experimental materials}

Preparation of wastelage and related activities were carried out in the Goat and Sheep farm, Department of Animal Science, Bangladesh Agricultural University, Mymensingh during the period from $24^{\text {th }}$ June to $22^{\text {th }}$ August 2014. The laboratory analysis was completed in the Animal Science and Animal Nutrition laboratory of the department of Animal Science and Animal Nutrition, respectively, Bangladesh Agricultural University, Mymensingh.

Caged layer excreta and rice straw were collected from Poultry Farm and field of Goat and Sheep Farm respectively, Bangladesh Agricultural University, Mymensingh. For the collection of layer droppings, polyethylene sheet was placed under the cage of birds in the poultry shed. During collection enough care was taken so that the layer droppings would be free from feather, sand or other materials. Molasses, sacks, air tight plastic containers and polythene sheet were purchased from available local market.

\subsection{Preparation of wastelage}

The experiment was laid out in a Complete Randomized Design (CRD) with 3 replicate in each treatment. The investigation was carried out to study the using fresh caged layer excreta with rice straw for making wastelage as a feed for cattle. The treatments under the study were $\mathrm{T}_{0}(0 \%$ caged layer excreta $+5 \%$ molasses $+95 \%$ rice straw), $\mathrm{T}_{1}\left(10 \%\right.$ caged layer excreta $+5 \%$ molasses $+85 \%$ rice straw), $\mathrm{T}_{2}(20 \%$ caged layer excreta $+5 \%$ molasses $+75 \%$ rice straw) and $\mathrm{T}_{3}(30 \%$ caged layer excreta $+5 \%$ molasses $+65 \%$ rice straw $)$. The amounts of all of the above ingredients were measured on DM basis.

Rice straw was collected just after harvesting the paddy. After collecting rice straw were chopped about $3-4 \mathrm{~cm}$ long. Then wastelage was prepared by mixing previously chopped rice straw with fresh poultry litter and molasses in varying ratios: 95:0, 85:10, 75:20, 65:30 and 5\% molasses in each treatment. For proper mixing, 
caged layer excreta and molasses were mixed primarily and then finally mixed with rice straw. When rice straws were properly mixed with caged layer excreta and molasses, these were placed into air-tight polythene sacks which were previously marked according to the treatment. Finally containers were kept in a room $\left(25\right.$ to $\left.28{ }^{\circ} \mathrm{C}\right)$ for 60 days for successful ensiling.

\subsection{Chemical analysis}

Portion of poultry droppings and rice straw were dried in the sun and then ground to pass through $40 \mathrm{~mm}$ mesh sieve. After grinding, the samples were subjected to chemical analysis for organic matter (OM), crude protein (CP), crude fiber (CF), ether extract (EE) and total ash (Ash) following the procedure of AOAC (2004). Chemical composition of ingredients used in the experiments is shown in Table 1.

Wastelage samples were collected to observe how many days need to get a good wastelage. Finally, they were opened at 60 days. Duplicate wastelage samples were taken and mixed thoroughly, one for DM and $\mathrm{pH}$ determination and another one were dried in oven at $55{ }^{\circ} \mathrm{C}$ for 72 hours for chemical analysis. $\mathrm{PH}$ of the wastelage sample was determined by using a digital laboratory $\mathrm{pH}-\mathrm{mV}$ meter (Ino. Lab., Germany) after putting $2 \mathrm{~g}$ sample in $50 \mathrm{ml}$ distilled water. To determine the nutritive value of the wastelage, respective dry samples were subjected to proximate analysis for dry matter (DM), crude protein $(\mathrm{CP})$, crude fiber $(\mathrm{CF})$, ether extract (EE), ash, nitrogen free extract (NFE) following the methods described by AOAC (2004). In vitro organic matter digestibility (IVOMD) and metabolizable energy (ME) content of wastelage were done following the procedure described by Menke et al. (1979).

\subsection{Statistical analysis}

The analysis of variance was done by using 'MSTAT' and 'SPSS' computer package program for a Complete Randomized Design, and differences among the treatment means were determined by Duncan's Multiple Range Test (DMRT).

\section{Results and Discussion}

\subsection{Physical properties and $\mathbf{P}^{\mathrm{H}}$ of wastelage}

The physical properties of wastelage of different treatments $\left(T_{0}, T_{1}, T_{2}\right.$ and $\left.T_{3}\right)$ are shown in Table 2 . All the treatments had good color and soft textures but controlled $\left(\mathrm{T}_{0}\right)$ treated wastelage remained hard. Fungus propagation was not observed in poultry droppings treated straw but some seen in controlled treatment. Among all the treatments, $\mathrm{T}_{1}(10 \% \mathrm{CLE})$ and $\mathrm{T}_{2}(20 \% \mathrm{CLE})$ had good smell but $\mathrm{T}_{3}(30 \% \mathrm{CLE})$ had pungent smell which was not acceptable by cattle. A pleasing aroma, good color and soft texture was obtained when poultry droppings were ensiled with maize forage (Harmon et al., 1975), citrus pulp or weeds (Hadjipanayiotou, 1982) and Oat forages (Khatun et al., 2013).

The $\mathrm{P}^{\mathrm{H}}$ of wastelage is shown in Figure 1. Significant differences $(\mathrm{p}<0.05)$ were observed among the treatments. The highest $\mathrm{P}^{\mathrm{H}}$ value was observed by treatment $\mathrm{T}_{0}$ followed by $\mathrm{T}_{1}, \mathrm{~T}_{2}$ and $\mathrm{T}_{3}$. It was observed that $\mathrm{P}^{\mathrm{H}}$ value decreased with the increase level of caged layer excreta. The lower $\mathrm{P}^{\mathrm{H}}$ of wastelage indicates good fermentation quality which was due to presence of molasses and higher water soluble carbohydrates in fodder that enhanced lactic acid production. Roothaert et al. (1992) indicated that ensiled materials should reach a $\mathrm{P}^{\mathrm{H}}$ of less than 5 in order to destroy fungus and other pathogens. In the present studies, $\mathrm{P}^{\mathrm{H}}$ values lower than 5 were attained in all wastelage indicates good fermentation quality.

\subsection{Chemical composition of wastelage}

The dry matter contents of wastelage of different treatments are shown in Table 3. It was observed that Dry Matter $(\mathrm{DM})$ content $(\mathrm{g} / 100 \mathrm{~g})$ of wastelage differed significantly $(\mathrm{p}<0.05)$ among the treatment groups. Ensiling with caged layer excreta significantly $(p<0.05)$ decreased the dry matter $(D M)$ content of wastelages among the treatments. DM content decreased linearly from 78.00 to $55.63 \%$ with increased level of caged layer excreta from 0 to $30 \%$ of the total dry matter. Another reason of decreasing the DM content in the study may be due to addition of water during ensiling. DM decreased from 22.58 to $20.83 \%$ in ensiled maize stover (Otieno et al., 1986) and from 29.1 to $26.5 \%$ (Hiep and Man, 2003). Snijders and Wouters, (2004) reported DM loss of $81 \%$ in ensiled maize stover. DM content was reduced from 28.0 to 26.4\%, with increasing the ensiling time from 2 to 4 months (Man and Wiktorsson, 2003. But, Khatun et al. (2013) reported that the increasing level of DM in ensiled Oat forage with increased level of caged layer excreta. Similar result was reported by Flachowsky and Hennig (1990).

The Organic Matter $(\mathrm{OM})$ content of the treatments is shown in Table 3. The present study indicates that the OM content was significantly $(\mathrm{p}<0.05)$ differed among the treatment groups. The OM content was the highest 
$\left(73.53^{\mathrm{a}} \pm 0.28 \%\right)$ in $\mathrm{T}_{1}$ and lowest $\left(67.72^{\mathrm{d}} \pm 1.35 \%\right)$ in $\mathrm{T}_{0}$ treatment groups of ensiling with caged layer excreta. OM is decreased with the urea treatment of maize stover (Smith et al., 1989). Kayongo et al. (1986) reported that OM content slightly increased with increasing time when maize stover ensiled with caged layer waste (nitrogen source) which supports the present findings. Due to ensiling time in the presence or absence of additives, organic matter may be increased or decreased, which may depend on different factors such as biochemical or microbial reactions during ensiling period.

Crude protein (CP) content of the wastelage was increased with increased proportion of CLE (Table 3). CP content significantly $(\mathrm{p}<0.05)$ increased steadily with adding CLE from $5.22 \%$ in wastelage with $10 \%$ caged layer excreta to $5.97 \%$ in wastelage with $30 \%$ caged layer excreta. Wastelage with $30 \%$ caged layer excreta $\left(\mathrm{T}_{3}\right)$ was found highest $(\mathrm{p}<0.05)$ than other treatments. The lowest $(4.26 \%) \mathrm{CP}$ content was found in $\mathrm{T}_{0}(0 \%$ CLE) treatment group. The CP content differed $(\mathrm{p}<0.05)$ with the addition of caged layer excreta (CLE). In contrast to the present findings, Daniels et al. (1983) reported that maize stover ensiled broiler litter for 6 weeks and found that CP was increased with increased proportion of poultry litter. Ngele et al. (2006) ensiled rice straw with poultry litter at different ratios and recorded the highest crude protein in ratio 50:50. CP content increased with the ensiling time increase when maize stover ensiled with nitrogen source CLE (Kayongo et al., 1986). Khatun et al. (2013) and Al-Rokayan et al. (1988) agree with the present findings. Both of them, reported that the crude protein of forages ensiled with broiler litter increased with increased proportion of poultry litter. Similar result has been reported by Hadjipanaytou (1984) and Flachowsky and Hennig (1990).

The crude fibre $(\mathrm{CF})$ content was decreased significantly $(\mathrm{p}<0.05)$ from 22.57 to $14.95 \%$ with the addition of caged layer excreta (0 to 30\%) is shown in Table 3. CF of straw is reduced with increasing the ensiling time, when ensiled with caged layer waste (nitrogenous source) (Kayongo et al., 1986). CF content of straw reduced with ensiling time (Man and Wiktorsson, 2003). Rasool et al. (1998) also observed a decline in NDF, hemicelluloses and cellulose (fiber component) in fodder ensiled with broiler litter and molasses. The decline in crude fiber might be due to hydrolysis of uric acid available in poultry litter to ammonia which can effectively break down the lignin bond in roughage (Ngele et al., 2006). Baba et al. (2010) who reported that when Kyasuwa hay (Pennisetum pedicellatum) ensiled with poultry litter, the CF content was decreased from $20.46 \%$ in treatment 80:20 to $15.95 \%$ in 50:50. The reason of CF decrease may be due to addition of poultry litter which contain lower CF than straw or stover, as in the present experiment water was added with the sample and also decomposition of silage materials, which was supported by Skultety et al. (1991) who reported that CF may be decreased with addition of water. Magar and Fontenot (1988) and Rasool et al. (1996) also observed a similar trend in rice straw ensiled poultry litter.

The Ether Extract (EE) content of wastelage of different treatments is shown in Table 3. The EE content of different treatments $\left(\mathrm{T}_{0}, \mathrm{~T}_{1}, \mathrm{~T}_{2}\right.$ and $\left.\mathrm{T}_{3}\right)$ of wastelage was $3.21,3.23,3.24$ and $3.25 \%$, respectively. There were no significant differences ( $>0.05$ ) among treatments. Baba et al. (2010) reported that when Kyasuwa hay (Pennisetum pedicellatum) ensiled with poultry litter, EE declined with increased proportion of poultry litter. It might be due to the higher content of EE extract in Kyasuwa hay used during that study.

The Ash content of different treatments $\left(\mathrm{T}_{0}, \mathrm{~T}_{1}, \mathrm{~T}_{2}\right.$ and $\left.\mathrm{T}_{3}\right)$ of wastelage was 25.08, 18.91, 17.90 and 17.70\%, respectively (Table 3). The Ash content was decreased significantly $(\mathrm{p}<0.05)$ with the increase of CLE. This result is not supported by Al-Rokayan et al. (1988), Flachowsky and Hennig (1990) and Khatun et al. (2013) who observed a linear increase in ash with increased proportion of broiler litter. It may be happened due to processing method or other environmental factors.

\subsection{In vitro organic matter digestibility (IVOMD) of wastelage}

The in vitro organic matter digestibility $(\mathrm{OMD})$ content $(\%)$ differed significantly $(\mathrm{p}<0.05)$ due to different levels of caged layer excreta (CLE). The in vitro organic matter digestibility (IVOMD) is shown in Figure 2. The highest in vitro OMD content $(\%)$ was produced by treatment $\mathrm{T}_{1}\left(57.51^{\mathrm{a}} \pm 0.81\right)$ and the lowest in vitro OMD (\%) was observed in $\mathrm{T}_{0}\left(55.36^{\mathrm{d}} \pm 0.18\right)$. In vitro OMD (\%) of Treatment $\mathrm{T}_{2}\left(56.95^{\mathrm{b}} \pm 1.08\right)$ and $\mathrm{T}_{3}\left(55.79^{\mathrm{c}} \pm 0.21\right)$ were statically identical and lower than that of OMD of $\mathrm{T}_{1}$ treatment. Khatun et al. (2013) agree with the present findings and suggested that ensiling Oat forage with up to 60\% CLE improve the in vitro organic matter digestibility and feeding value of wastelage. The results of this study was similar to Reddy (1989) who observed increase in vitro organic matter digestibility of rice straw ensiled with animal excreta and rumen digesta. In vitro organic matter digestibility of ensiled poultry manure and crop residue was increased with increased the level of poultry manure (Saylor and Long, 1972). The observations in present study was slightly differing than that of previous one. It might be due to the difference of ensiling materials and level of poultry manure. 
3.4. Metabolizable Energy (ME) content of wastelage

Metabolizable energy content of wastelage is shown in Figure 3. The values for metabolizable energy (ME) content $(\mathrm{MJ} / \mathrm{kg} \mathrm{DM})$ of wastelage was differed significantly $(\mathrm{p}<0.05)$ among the treatment. The highest ME was produced by treatment $\mathrm{T}_{1}\left(8.12^{\mathrm{a}} \pm 0.30 \mathrm{MJ} / \mathrm{Kg} \mathrm{DM}\right)$ which was statistically identical to $\mathrm{T}_{2}\left(8.06^{\mathrm{ab}} \pm 0.20 \mathrm{MJ} / \mathrm{Kg}\right.$ $\mathrm{DM})$ but higher than that of $\mathrm{T}_{3}\left(7.84^{\mathrm{c}} \pm 0.04 \mathrm{MJ} / \mathrm{Kg} \mathrm{DM}\right)$ treatment. The lowest ME was produced by control treatment $\left(7.65^{\mathrm{d}} \pm 0.16 \mathrm{MJ} / \mathrm{Kg} \mathrm{DM}\right)$. Similar trend was also reported by Ali et al. (1994), who indicated that in vitro DM digestibility and ME were increased in treated compared with untreated stover after ensiling. Khatun et al. (2013) also stated almost similar findings where in vitro organic matter digestibility and metabolizable energy also increased significantly $(\mathrm{p}<0.05)$ with the increase of CLE and maximum value $(65.5 \%$ and 9.10 $\mathrm{MJ} / \mathrm{kg}$ DM, respectively) was obtained in wastelage with 40\% CLE, which was statistically identical to $60 \%$ CLE ensiled with Oat forage.

Table 1. Chemical composition of ingredients used in experiments.

\begin{tabular}{lll}
\hline \multirow{2}{*}{$\begin{array}{c}\text { Chemical composition } \\
\text { (g/100g DM) }\end{array}$} & \multicolumn{2}{c}{ Ingredients } \\
\cline { 2 - 3 } DM \% (Fresh basis) & 30 & Rice straw \\
OM & 78.87 & 89.31 \\
CP & 18.45 & 81.78 \\
CF & 11.04 & 03.01 \\
EE & 1.89 & 31.84 \\
NFE & 51.49 & 04.47 \\
Ash & 21.13 & 31.77 \\
\hline
\end{tabular}

Table 2. Effect of different treatments on physical properties of wastelage.

\begin{tabular}{lllll}
\hline \multirow{2}{*}{ Parameters } & \multicolumn{4}{c}{ Wastelage with different percentage of caged layer excreta } \\
\cline { 2 - 5 } & $\mathbf{T}_{\mathbf{0}}$ & $\mathbf{T}_{\mathbf{1}}$ & $\mathbf{T}_{\mathbf{2}}$ & $\mathbf{T}_{\mathbf{3}}$ \\
\hline Color & Light brown & Light Brown & Light chocolate & Brown \\
Smell & Straw & Acceptable smell & Good & Pungent \\
Texture & Hard & Soft & Moderate soft & Very soft \\
Fungus & Present & Absent & Absent & Absent \\
\hline
\end{tabular}

$\mathrm{T}_{0}(0 \%$ caged layer excreta $+5 \%$ molasses $+95 \%$ rice straw $), \mathrm{T}_{1}(10 \%$ caged layer excreta $+5 \%$ molasses $+85 \%$ rice straw), $\mathrm{T}_{2}(20 \%$ caged layer excreta $+5 \%$ molasses $+75 \%$ rice straw $)$ and $\mathrm{T}_{3}(30 \%$ caged layer excreta $+5 \%$ molasses + $65 \%$ rice straw).

Table 3. Effects of different level of caged layer excreta on the chemical composition of wastelage.

\begin{tabular}{lllll}
\hline \multirow{2}{*}{ Parameters (\%) DM basis } & \multicolumn{3}{c}{ Wastelage with different percentage of caged layer excreta } \\
\cline { 2 - 5 } & $\mathbf{T}_{\mathbf{0}}$ & $\mathbf{T}_{\mathbf{1}}$ & $\mathbf{T}_{\mathbf{2}}$ & $\mathbf{T}_{\mathbf{3}}$ \\
\hline Dry matter (Fresh basis) & $78.00^{\mathrm{a}} \pm 2.01$ & $72.20^{\mathrm{b}} \pm 2.62$ & $60.61^{\mathrm{c}} \pm 0.30$ & $55.63^{\mathrm{d}} \pm 1.08$ \\
Organic matter & $67.72^{\mathrm{d}} \pm 1.35$ & $73.53^{\mathrm{a}} \pm 0.28$ & $70.58^{\mathrm{b}} \pm 0.17$ & $68.99^{\mathrm{c}} \pm 1.09$ \\
Crude Protein & $4.26^{\mathrm{d}} \pm 0.33$ & $5.22^{\mathrm{c}} \pm 0.57$ & $5.46^{\mathrm{b}} \pm 3.05$ & $5.97^{\mathrm{a}} \pm 1.08$ \\
Crude fibre & $22.57^{\mathrm{a}} \pm 0.36$ & $17.08^{\mathrm{b}} \pm 0.23$ & $15.50^{\mathrm{c}} \pm 0.71$ & $14.95^{\mathrm{d}} \pm 3.35$ \\
Ether extract & $3.21^{\mathrm{a}} \pm 0.69$ & $3.23^{\mathrm{a}} \pm 0.72$ & $3.24^{\mathrm{a}} \pm 0.76$ & $3.25^{\mathrm{a}} \pm 0.78$ \\
Ash & $25.08^{\mathrm{a}} \pm 3.23$ & $18.91^{\mathrm{b}} \pm 2.94$ & $17.90^{\mathrm{c}} \pm 0.63$ & $17.70^{\mathrm{c}} \pm 0.33$ \\
\hline
\end{tabular}

$\mathrm{T}_{0}(0 \%$ caged layer excreta $+5 \%$ molasses $+95 \%$ rice straw $), \mathrm{T}_{1}(10 \%$ caged layer excreta $+5 \%$ molasses $+85 \%$ rice straw), $\mathrm{T}_{2}(20 \%$ caged layer excreta $+5 \%$ molasses $+75 \%$ rice straw $)$ and $\mathrm{T}_{3}(30 \%$ caged layer excreta $+5 \%$ molasses + $65 \%$ rice straw). ${ }^{a, b, c, d}$ values in the same row with different superscripts differ significantly $(\mathrm{p}<0.05)$ among treatments. 


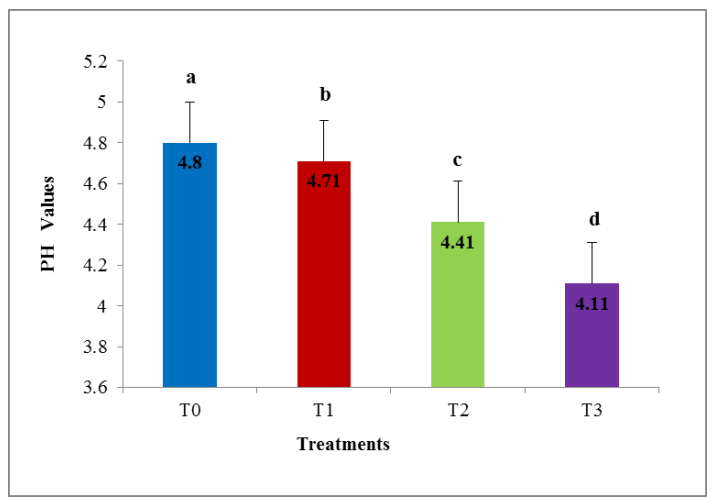

Figure 1. $\mathrm{P}^{\mathrm{H}}$ values of different wastelages with different level of CLE and rice straw where, $\mathrm{T}_{0}(0 \%$ caged layer excreta $+5 \%$ molasses $+95 \%$ rice straw $), T_{1}(10 \%$ caged layer excreta $+5 \%$ molasses $+85 \%$ rice straw $), T_{2}(20 \%$ caged layer excreta $+5 \%$ molasses $+75 \%$ rice straw $)$ and $T_{3}(30 \%$ caged layer excreta $+5 \%$ molasses $+65 \%$ rice straw). Bar represents mean $\pm S E$. ${ }^{a}, b, c, d$ values in the same row with different superscripts differ significantly $(\mathbf{p}<0.05)$ among treatments.

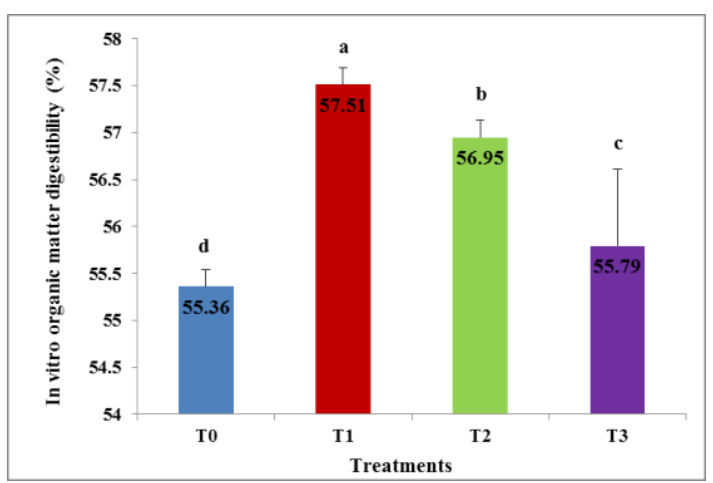

Figure 2. In vitro organic matter digestibility (\%) of wastelage with different level of caged layer excreta and rice straw where, $T_{0}(0 \%$ caged layer excreta $+5 \%$ molasses $+95 \%$ rice straw $), T_{1}(10 \%$ caged layer excreta $+5 \%$ molasses $+85 \%$ rice straw $), T_{2}(20 \%$ caged layer excreta $+5 \%$ molasses $+75 \%$ rice straw $)$ and $\mathrm{T}_{3}(30 \%$ caged layer excreta $+5 \%$ molasses $+65 \%$ rice straw $)$. Bar represents mean $\pm \mathrm{SE} .{ }^{\mathrm{a}, \mathrm{b}, \mathrm{c}, \mathrm{d}}$ values in the same row with different superscripts differ significantly $(\mathbf{p}<0.05)$ among treatments.

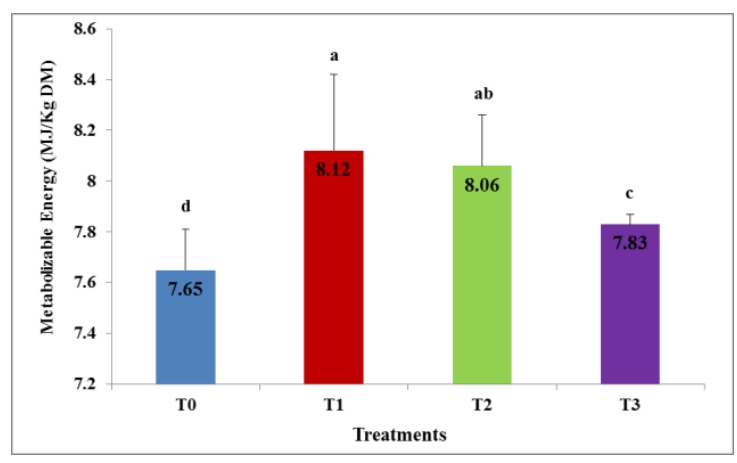

Figure 3. Metabolizable Energy content (MJ/Kg DM) of wastelage at different level of cage layer excreta and rice straw where, $T_{0}(0 \%$ caged layer excreta $+5 \%$ molasses $+95 \%$ rice straw $), T_{1}(10 \%$ caged layer excreta $+5 \%$ molasses $+85 \%$ rice straw $), T_{2}(20 \%$ caged layer excreta $+5 \%$ molasses $+75 \%$ rice straw $)$ and $\mathrm{T}_{3}(30 \%$ caged layer excreta $+5 \%$ molasses $+65 \%$ rice straw $)$. Bar represents mean $\pm \mathrm{SE}$. ${ }^{\mathrm{a}, \mathrm{b}, \mathrm{c}, \mathrm{d}}$ values in the same row with different superscripts differ significantly $(\mathbf{p}<0.05)$ among treatments.

\section{Conclusions}

The use of poultry droppings as a feed ingredient for livestock may be a convenient option of proper recycling of poultry droppings as well as reduce wastes and environmental pollution and also provide inexpensive feed 
components for ruminants. The addition of caged layer excreta (CLE) and ensiling time helps to improve the nutritive value, physical quality and preservation capacity of rice straw. Rice straw can be ensiled with up to 20\% CLE and 5\% molasses to improve the feeding values of wastelage highly acceptable for cattle feeding. Further investigation is needed with in-vivo feeding trial to justify the present findings.

\section{Conflict of interest}

None to declare.

\section{References}

Ali I, JP Fontenot and VG Allen, 1994. Fermentation characteristics, chemical changes and in vitro dry matter digestibility of corn stover treated with different sources of nitrogen (small silo study). J. P. Vet., 14: 185193.

Al-Rokayan SA, Z Naseer and SM Chaudhry, 1988. Nutritional quality and digestibility of sorghum-broiler litter silages. Anim. Feed Sci. Tech., 75: 65-73.

AOAC (Association of Official Analytical Chemists), 2004. Official Methods of Analysis (17 ${ }^{\text {th }}$ Edn.). Washington, DC, pp. 1-34.

Baba M, T Uba and AR Halim, 2010. Nutritive value of Kyasuwa hay (Pennisetum pedicellatum) ensiled with poultry litter at varying proportions. Research J. Anim. Sci., 4: 117-120.

Bhattacharya AN and JC Taylor, 1975. Recycling animal waste as a feedstuff. J. Anim. Sci., 41: 1438-1457.

Cooper DP, RD Goodrich and JC Meiske, 1974. Soybean meal, urea and chicken manure as protein sources for growing beef calves. J. Anim. Sci., 39: 997 (Abstr.).

Daniels LB, MJ Smith, OT Stallcup and JM Rakes, 1983. Nutritive value of ensiled broiler litter for cattle. Anim. Feed Sci. Technol., 8: 19-24.

Douglas RB, 1990. Studies on the utilization potential of alternative feed ingredients in livestock production. J. Anim. Prod., 12: 345-348.

El-Sabban FF, JW Bratzler, TA Long, DEH Frear and RF Gentry, 1970. Value of processed poultry waste as a feed for ruminants. J. Anim. Sci., 31: 107-111.

Flachowsky G and A Hennig, 1990. Composition and digestibility of untreated and chemically treated animal excreta for ruminants- A review. Biol. Waste., 31: 17-36.

Fontenot JP, 1990. Assessing animal-waste feeding: nutritional guideline and safety consideration. Anim. Nutr. Health., 37: 12-15.

Fontenot JP, KEJ Webb, BW Harmon, RE Tucker and WEC Moore, 1971. Studies of processing, nutritional value and portability of broiler litter for ruminants. Proc. Intern. Symp. on Livestock Wastes., ASAE, St. Joseph, MI, pp. 301.

Goering HK and LW Smith, 1977. Composition of the corn plant ensiled with excreta or nitrogen supplements and its effect on growing weathers. J. Anim. Sci., 44: 452 (Abstr.).

Hadjipanayiotou M, 1982. Laboratory evaluation of ensiled poultry litter. Animal production., 35: 157-161.

Hadjipanayiotou M, 1984. The use of poultry litter as ruminant feed in Cyprus. World Animal Review., 49: 3238.

Harmon BW, JP Fontenot and KEJ Webb, 1975. Ensiled broiler litter and corn forage. II. Digestibility, nitrogen utilization and palatability by sheep. J. Anim. Sci., 40: 156-160.

Harvey RWJW, MH Spears, Poore and JH Smith, 1996. Broiler and turkey litter as protein supplements for growing cattle. North Carolina Agricultural Res. Service Tech., 308: 78-82.

Hiep NV and NV Man, 2003. Dairy cattle feed from stover derived from mature and immature maize crops in small holder crop-livestock production system in Vietnam. University of Agriculture and Forestry, Thu Duc, Ho Chi Minh city, Vietnam. manmy@hcm.vnn.vn

Jayasuriya MCN and GR Pearce, 1983. The effect of urease enzyme on treatment time and the nutritive value of straw treated with ammonia as urea. J. Anim. Feed. Sci. Technol., 6: 123-131.

Kayongo SB, MM Wanyoike, PN Nayaga, T Maitho and PN Mbugua, 1986. Caged layer waste as nitrogen source in crop- residue utilization. Department of Animal Production, Faculty of Veterinary Medicine, University of Nairobi, Nairobi, Kenya.

Khatun H, RI Khan and M Moniruzzaman, 2013. Preparation of wastelage with poultry droppings and oat forage (Avena sativa) as a feed for cattle. J. Environ. Sci. \& Natural Resources., 6: 233-237.

Magar SM and JP Fontenot, 1988. Nutritional value of ensiled deep pit caged layer waste-corn forage mixtures. Virginia Technical Livestock Research, Report No 7, Blacksburg, pp. 133-136. 
Man N and H Wiktorsson, 2003. The effect of molasses on quality, feed intake and digestibility by heifers of silage made from cassava tops. Department of Animal Nutrition, UAF, Thu Duc, Ho Chi Minh City, Vietnam.

Martin SA, MA Mccann and WD Waltman, 1998. Microbiological survey of Georgia poultry litter. J. Appl. Poultry Res., 7: 90-98.

Mavimbela DT, 2000. The nutritional value of broiler litter as a feed source for sheep during periods of feed shortage. PhD Thesis, Department of Animal and Wildlife Sciences, Faculty of Agriculture, University of Pretoria.

Menke KH, L Raab, A Salewski, H Steingass, D Fritz and W Schneider, 1979. The estimation of the digestibility and metabolizable energy content of ruminant feeding stuffs from the gas production when they are incubated with rumen liquor in vitro. J. Agric. Sci. Camb., 93: 217-222.

Ngele MA, TA Adegbola and SES Bogoro, 2006. Nutritive value of rice straw treated with poultry litter. Proceedings of the $31^{\text {st }}$ annual conference of Nigerian society for animal production, March 12-15, Bayero University, Kano, pp. 18-21.

NRC (National Research Council), 1983. Underutilized resources as animal feedstuffs. National academy press, Publication 1754. NRC, Washington, DC, USA.

Otieno K, JFM Onim and MN Mathuva, 1986. A gunny bag ensiling technique for small scale farmers in Western Kenya. Ministry of Livestock Department/SR-CRSP, Maseno, Kenya.

Rasool S, MA Sial, Ahsan-ul-Haq and A Jamil, 1998. Chemical changes during ensiling of sudax fodder with broiler litter. Anim. Feed Sci. Tech., 72: 347-354.

Rasool S, SH Hanjra and A Jamil, 1996. Effect of ensiling sudax fodder with broiler litter and Candida yeast on the changes in different fiber fractions. Anim. Feed Sci. Tech., 57: 325-333.

Reddy GVK and MR Reddy, 1989. Nutritive value of rice straw (Oryza sativa) ensiled with animal excreta and rumen digesta. J. Anim. Feed Sci. Technol., 24: 69-81.

Roothaert RL and RW Matthewman, 1992. Poultry wastes as foods for ruminants and associated aspects of animal welfare - Review. American J. Anim. Sci., 5: 593-600.

Saylor WW and TA Long, 1972. Laboratory evaluation of ensiled poultry waste. J. Anim. Sci., 39:139 (Abstr.).

Sitorus P, Subandriyo and Wibowo, 1980. Utilization of layer litter as a feedstuff in lactating dairy cows. Bulletin Lembaga Penelitian Petemakan., 25: 1-8.

Skultety M, N Skultetyova and E Bencova, 1991. Effect of different proportions of dry maize straw on fodder beet silage quality. Pol'nohospodarstvo., 37: 648-654.

Smith T, C Chakanyuka, S Sibanda and B Manyuchi, 1989. Maize stover as a feed for ruminants. Department of Research and Specialist Services, Grasslands Research Station, Marondera, Zimbabwe. Proceedings of a workshop held in Malawi, ARNAB, ILCA, Addis Ababa, Ethiopia., pp. 218-231.

Snijders PJM and AP Wouters, 2004. Silage quality and losses due to ensiling of Napier grass, Colombus grass and Maize stover under small holder conditions in Kenya. FAO electronic conference on tropical silage.

SPSS, 2007. SPSS Inc. Released 2007, Statistical Package System Software (SPSS) for windows, version 16.0. Chicago, SPSS Inc.

Strickler RH, 1977. Deep stacking broiler litter as a means of storage for use in feeding beef cows In: alternate nitrogen sources for ruminants, pp. 56-57. Conference, 9-11 November 1977, Atlanta, Georgia, USA. 